\title{
Accounting Practices of Small and Medium Enterprises in Rangpur, Bangladesh
}

\section{Uddin $\mathbf{R}^{1}$, Biswas $\mathrm{T}^{2}$, Ali $\mathbf{J}^{3 *}$ and Khatun $\mathbf{M S}^{4}$}

${ }^{1}$ Department of Accounting and Information Systems, Begum Rokeya University, Bangladesh

${ }^{2}$ Department of Business Administration, Mawlana Bhashani Science and Technology University (MBSTU), Bangladesh

${ }^{3}$ Department of Management Studies, Begum Rokeya University, Bangladesh

${ }^{4}$ Department of Marketing, Begum Rokeya University, Bangladesh

\begin{abstract}
Purpose: The purpose of the study is to examine and evaluate the current status of adopting and implementing the accounting system and practices of Small and Medium Enterprises (SMEs) in Rangpur region as well as to analyze the extent to which accounting information is being used in measuring financial performance by SMEs with limitations.

Approach: This empirical study is based on the primary (face to face interview and interview over the phone using questionnaire) and secondary (Various book, published research papers, websites, statistical report of BBS and annual report of BB) sources of data where total selected sample 30 enterprises out of sample population 66 enterprises. Different statistical tools (hypothesis testing, co-relation analysis and Chi-Square test) are used to analyze and find the result of the study. The designated measures of accounting system are records of document, financial statement, audited financial statement, accounting methods, accounting basis, quality of accounting information and entrepreneur having accounting knowledge.

Findings: The findings of the study reveal that only $20 \%$ of enterprises follow the accounting system directly and the other $80 \%$ of the enterprises follow the accounting system indirectly. Correlation analysis signposted that among the seven selected independent variables keep accounting records, prepare financial statement, quality information and basis of accounting had significant positive relationships with the accounting system. Null hypothesis is rejected and alternative hypothesis is accepted. So the result showed that SMEs of Rangpur follow accounting system directly or indirectly. The study found that out of 30 enterprises, 10 SMEs enterprises prepared income statement, 14 SMEs prepared cash flow statement and 6 SMEs prepared all statements.
\end{abstract}

Originality/Value: This paper provides useful information to the concerned authority (Bangladesh Bank, Bangladesh Bureau of Statistics, SME foundation of Bangladesh) as well as other stakeholders including SMEs owners, researchers and accounting practitioners who are directly or indirectly involved in SMEs.

Keywords: Accounting system; Practices; Small and Medium Enterprises (SMEs); Rangpur; Empirical evaluates

\section{Introduction}

Accounting plays a critical role in the success or failure of contemporary business institutions. Accounting systems are responsible for recording, analyzing, monitoring and evaluating the financial condition of companies, preparation of documents necessary for tax purposes, providing information support to many others organizational functions. Accounting systems provide a source of information to owners and managers of SMEs operating in any industry for the use in measuring financial performance [1]. There are 66 Small and medium enterprises in Rangpur. Most of the enterprises are very small and some are medium. Establishment of SMEs in Rangpur is increasing day by day. Basic objective of the entrepreneur is to create more job opportunity and development of north region. All of the enterprises use accounting system. Some enterprises used accounting system directly and some are used indirectly. Directly used means those enterprise followed accounting system properly and they have knowledge about accounting system. But in Rangpur $80 \%$ SMEs indirectly used accounting system (under this $80 \%$ most are sole proprietorship). These enterprises used accounting system but they used it without having knowledge that means they use voucher, prepare income statement, prepare cash flow statement and also used double entry system as per their need but they do not know it's called accounting system. 20\% SMEs or medium enterprises those follow accounting system is not standard accounting system. They didn't equipped financial statement and didn't publish any annual report. The main reasons behind having such poor accounting environment are the lack of public accountability, lack of regulations, lack of mandatory audit requirement, and lack of resources. Owners and managers need to understand the role of accounting information in the form of clear financial statements in ensuring proper justification for business transactions and state of affairs [2]. There is a significant negative impact of poor accounting practices on the growth and sustainability of SMEs. According to the European Federation of Accountants, business decision need to be supported by good quality financial information which need to be relevant, user friendly and in timely manner. But many owners or managers operate their business activities without any accounting or financial judgment, take many important investment and credit decision without any accounting and financial analysis. Sometimes owners or managers of the SMEs fail to understand about the actual financial status of their own business. Researcher selected

*Corresponding author: Md. Julfikar Ali, Research Student, Department of Management Studies, Begum Rokeya University, Rangpur, E-mail: julfikar05.bd@gmail.com

Received September 26, 2017; Accepted October 27, 2017; Published November 07, 2017

Citation: Uddin R, Biswas T, Ali J, Khatun MS (2017) Accounting Practices of Small and Medium Enterprises in Rangpur, Bangladesh. J Bus Fin Aff 6: 298. doi: 10.4172/2167-0234.1000299

Copyright: $\odot 2017$ Uddin R, et al. This is an open-access article distributed under the terms of the Creative Commons Attribution License, which permits unrestricted use, distribution, and reproduction in any medium, provided the original author and source are credited. 
that topic to know the actual landscape of accounting system in SMEs.

\section{Literature Review}

This part of the study shows the foregoing reflected studies of the accounting system form pros and cons corner of the study. Basically accounting system is worldwide live out that circulated some parallel part of the organizational system, Ismail and King [3], focused on correct position in relation to accounting information requirements and accounting system capacity to generate information in the context of Malaysian SME manufacturing firms where AIS alignment strongly related to the six influencing factors (IT sophistication, owner/manager knowledge, owner/manager commitment, external expertise, internal expertise and firm size). Zhou [4] identified some problems in conducting a study (Undeveloped SMEs Accounting Software, inadequate managerial attention and untrained managers and employees regarding accounting information systems) relating to implement accounting systems that SMEs faced and gave some suggestions (Development of SMEs accounting software, strengthen the responsibility of administering authority, educational depth of accounting information of the authority as well as software developers and effective training to the managers and employees to the overall operations of SMEs) to resolve those problems for making SMEs better services. Maseko and Manyani [1] carried out an investigative study to reveal the accounting practices (record keeping) for performance measurement of SMEs in Zimbabwe using Bindura as a case. This study focused that most of the SMEs did not keep complete accounting records due to lack of accounting knowledge for this reason it was not possible for measuring financial performance through using accounting information. Okoli [5] conducted a study in Enugu, South East of Nigeria for evaluating the accounting systems of small scale enterprises due to the high failure rate. The result of the study revealed that a significant number of enterprises followed single entry accounting system as a record keeping tool for the flexibility of its usage and for ensuring profitability. Fatoki [6] focused on financial planning and control, financial analysis, accounting information, management accounting, investment appraisal and working capital management for proper financial management practices whereas micro enterprises did not follow financial planning and control, financial analysis and investment appraisal but those enterprises maintained purchase and sales books as to keep the record of the business transactions. AL Smirat [7] conducted a research regarding the use of accounting information of small and medium enterprises (SMEs) in south Jordan and found most of the SMEs followed single entry accounting system for its simplicity and recommended good accounting practices would improve the developed operations of small and medium sized enterprises (SMEs). Olatunji [8] revealed the main objective of the study to examine the interrelationship between accounting system and the corporate performance of small and medium scale enterprises and found that adoption of sound accounting system has a significant impact on the performance of small and medium scale enterprises. Amako [2] investigated in the study that sound accounting practices (maintaining proper books of accounts) helped to emphasize proper financial planning and control but result of the study found that most of the SMEs Kumasi, Ghana failed to keep and maintain complete accounting records. Velankar [9] explored a study regarding e-accounting practices/accounting systems of SMEs at Madhya Pradesh in India and found that majority of SMEs followed accounting software and satisfied (Tally, sage, Excel, QuickBooks and others) to reduce clerical works rather than manual recording and book keeping works and maintain accounts receivable, accounts payable, inventory management, payroll, fixed assets management bank reconciliation and cash management functions effectively. Ntim [10] revealed in the study that SMEs kept at least one books of accounts to record transactions, establish various accounting control for the simplicity of operations and thus overall accounting system of SMEs are influenced by some crucial factors (i.e., the size of firm, age of business and engagement of accounting personnel). Aforementioned study is the basis of different nations and perceptive issues of the accounting practices that describe the accounting system uses from different angles. It is really a matter of issues the small and, medium enterprises now feat the spaces of ongoing accounting system of Bangladesh as for the tremendous trend of accounting system. Keeping pace with the streaming accounting system issue study is profoundly concerned with accounting system of small and medium enterprise of Rangpur beyond aforementioned studies gap of the literature.

\section{Background of the Study}

An accounting system is a methodical, well-organized scheme for as long as accurate financial information and controls. Thus accounting systems show the books, records, voucher, files and other related supporting data resulting from the application of accounting processes The contribution of SMEs in Bangladesh is noticeable than other country but used accounting system in SMEs are rare. They may lack the sophistication to apply the detailed accounting processes, yet the value of accounting systems to these businesses is quite noticeable. Variety of SME products are producing in Bangladesh. These products are namely Shotorongi, door mate, tablemate, shoe, hand bag, school bag, papos, shaky, wall mate, leather and baby products. But in abroad most of the SMEs manufacture tobacco product, wearing product, leather product, wood product, paper and paper product, rubber product and plastic product etc. here is a board consensus that a vibrant SME sector is one of the principal driving forces in the development of the economy of Bangladesh. There are 66 small and medium enterprises in Rangpur arena. Among of these enterprises researcher selected 30 small and medium enterprises in central Rangpur arena. Findings showed that only $20 \%$ enterprise used accounting system and $80 \%$ enterprises did not used accounting system. Though most of the SMEs in Rangpur didn't used accounting system directly or without having any accounting knowledge they used some statements and voucher but their opinion reveals that as soon as possible they would try to follow accounting system for better performance.

\section{Objective of the Study}

The major objective of the study is to examine and evaluate the current status of adopting and implementing the accounting system and practices of Small and Medium Enterprises (SMEs) in Rangpur region. There are some specific objectives relating to the study are showing below:

- To analyze the extent to which accounting information is being used in measuring financial performance by SMEs.

- To examine the contribution of SMEs to GDP growth in Bangladesh and contribution of SMEs in Rangpur to GDP.

- To describe the limitation of small and medium enterprises to implementing accounting system.

- To make some recommendation for the overall issues.

\section{Methodology of the Study}

This study is exploratory in nature that seeks to determine the state of accounting system in small and medium enterprise in Rangpur. 
To conduct study, there methodological issue is one of the prime considerations for yielding of valid and reliable findings in consistent manner. Data of research collected both qualitative and quantitative in nature. However, the methods and operational procedures followed in conducting this study has been described in the subsequent sections of this chapter

\section{Extent of the study}

The study was conducted in the small and medium enterprises in Rangpur at the purposive basis. There are 66 listed SMEs in Rangpur district, the researcher selected these enterprises those are located in nearly Rangpur. The study areas are Mahigonj, BoroDorga, Alomnagor, C.O Bazar, NisbatGonj, Lahirir hat, Boiragigonj and Mithapukur in Rangpur.

\section{Source of the data}

Data should be collected from primary source and secondary source. The researcher used entrepreneur and employees as a primary data source and to find out the impact of SME in the economy or contribution of SMEs in the development of economy researcher collected data from secondary sources.

Primary Data: Data collected from the sample enterprise through interview and by communicating with respondent over phone. Adequate rapport established so that the respondents did not felt hesitant to provide actual information. Whenever any respondent faced difficulty in understanding a particular question, extra care took to explain the same clearly. No serious constraints were faced in collecting data. Primary data collected through a questionnaire including both structured and unstructured interview.

Secondary Data: Secondary data collected from various books, published journals, articles, research paper, internet website, reports of Daily star newspaper, Bangladesh Bureau of Statistics Notebook (2013), Preliminary reports and annual report of Bangladesh Bank (2013).

\section{Sample construction and addressing}

Random sampling technique used to collect data from the selected enterprise and the respondent. The study constructed sample size 100 including four parties. To find out the actual landscape of accounting system researcher took 30 enterprises, to know the employees having accounting knowledge or not researcher took 50 employees of selected enterprises and to know the market position of SMEs product, quality of the product, price of the product researcher took 18 customer while 2 member of Bangladesh Bureau of Statistics were took to know the contribution of SMEs to GDP in Bangladesh. Primary data collected from 30 enterprises those are nearly situated in Rangpur. The enterprises are Classical handmade products industries bd (Mahigonj), Karuponno Company (Medical more), Karushilpo Company (Lahirirhat, Bodorgonj), Charushi Shotorongi, Shotorongi polli, Rangpur handy craft, Anoyara Shuiter Mills Ltd, A.R Karushipo, Rangpur Hosto shilpo, ongona karu ponno and boutique, Nasir handy craft -C.O Bazar, Hamida karu shilpo, Boubazaar,Rangpur city. The SMEs in Rangpur region constituted the population of this study. There $\mathrm{N}=$ total population=273 (66 enterprises, 150 employee, 60 customer and 3 member of Bangladesh Bureau of Statistics), $\mathrm{n}=$ sample population $=100$ ( 30 enterprise, 50 employee, 18 customer and 2 member of Bangladesh Bureau of Statistics). In the study, no conventional systems of sampling procedure have been followed. Researcher selected 100 respondents which constituted $36 \%$ of the total population was the total sample strength of the study. One hundred
(100) respondents were selected randomly as the sample of the study.

\section{Survey}

Data has been collected by field survey from 30 enterprises in Rangpur arena. The researcher had selected manufacturing enterprise those are mainly handy product enterprise and jute product enterprise as sample. Data should be collected through questionnaire. The questionnaire included three major parts: First part covers the demographic profile of the respondents. Second part covers the question that is desirable to classify respondents into whether they accounting system or not. Finally after the classification, respondents were asked to present their reason why they maintained or did not maintain accounting records.

\section{Statistical analysis and processing}

The collected data were processed and analyzed by simple tabular technique and hypotheses. Researcher used graphical representation, frequency table etc. It will eventually lead researcher to the conclusion of his/her survey. The statistical measures such as range, mean, standard deviation and percentage were used for describing both the independent and dependent variables. Tables were also used in presenting data for clarity of understanding. All the tables related to the study are shown in Appendix.

\section{Study hypothesis}

Research hypothesis is an unproven statement, which helps the researcher to draw the suggestion on the hypothetical assumption whether it is true or false based on some specific statistical tests. For this study, the following hypotheses (at 95\% confidence level) are developed, which are also to be tested.

\section{Ho=SMEs of Rangpur don't follow accounting system. \\ $\mathrm{H1}$ =SMEs of Rangpur follow accounting system.}

[Ho=Null hypothesis and $\mathrm{Hl}=$ Alternative hypothesis $]$.

\section{Limitations of the Study}

Accounting system in Small and Medium Enterprises is a vast subject, but when the researcher collected data from enterprise entrepreneur and employer did not all reliable related to the questionnaire. The report was completed based on secondary and primary data which had to be taken from numerous respondents. Therefore there might be few errors while collecting data from 30 enterprises in Rangpur, a lot of difficulties have been faced by the researcher especially in data collection. When the SMEs actual scenario and purchase book, sales book, cash book and other statement was needed by the researcher, the entrepreneurs or their representatives expressed negative attitude at the initial stage but finally they give some answer Most of the entrepreneurs, manager and project manager aborted some questions in the questionnaire and rendered all positive information. They created restriction in question to the employee. Number of entrepreneur and managers were refuse to give interview or say no to communicate with researcher so there have no chance to get any information about the enterprises. In such situation for collecting data the researcher need to seek other enterprises which was not quite easy.

\section{The Conceptual Framework of the Study}

On the conceptual framework of the study researcher had classify research variable into two major parts; one is dependent variable, and 
another is independent variable. The dependent variable is accounting system in small and medium enterprises. Independent variables are name of the respondents, relation with SMEs, and knowledge about accounting system, accounting methods and basis used by SMEs, financial statement prepared by SMEs and decision making process. For all independent variable researcher did not used liker scale. To find out the result of accounting used by SMEs directly or indirectly researcher used yes and no as response from the entrepreneur. If the respondent answered yes, then asked the entire system followed by SMEs. But if the entrepreneur answered no then the researcher asked the limitation behind it's to use accounting system (Figure 1).

\section{Findings and Analysis of the Study}

In this study data has been collected from four parties (Entrepreneur, employee, customer and member of BBS) of Rangpur region. Here data collected from entrepreneur and employees was analyzing first. Total sample size for entrepreneurs and employees were 80 . According to the objectives collected data analyzed under.

\section{Data interpretation and analysis}

Accounting system followed by SMEs to the study purpose researcher collected data from selected 30 SMEs as sample of the research. The researcher found that only six enterprises directly used accounting system and 24 indirectly used accounting system in Rangpur. 20\% SMEs followed accounting system directly and $80 \%$ enterprises used or followed accounting system indirectly shown in Appendix 1.

Types of accounting records kept by SMEs: Accounting records are voucher, journal, ledger and trial balance etc. In Rangpur $60 \%$ enterprises records voucher as a documents of the enterprise, $20 \%$ enterprises kept journal and 20 kept all (voucher, journal, ledger and trial balance) as records of documents as shown in Appendix 2. Among 30 enterprises 24 enterprises records voucher as documents and 6 enterprises records journal while 6 enterprises records (voucher, journal and ledger) for their enterprises. In the above diagram $1=$ voucher, $2=$ journal, $3=$ =Ledger and $4=$ all of the records. Here showed that no enterprise separately records ledger for their enterprises.

Financial statement prepared by SMEs: To know the financial performance and taking better decision for the enterprises prepared financial statement is necessary. Financial statements are income

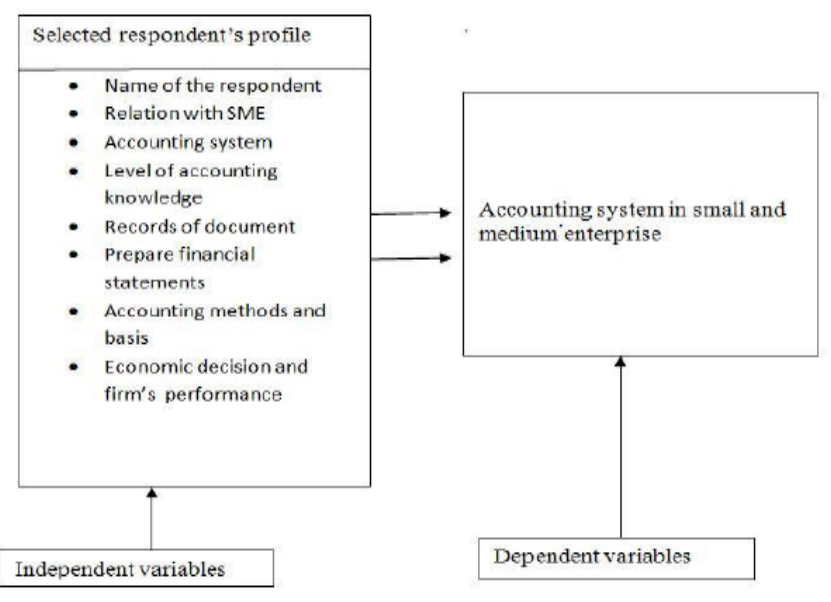

Figure 1: The conceptual framework of the study. statement, cash flow statement, balance sheet, owner's equity statement and notes and disclosure. The researcher selected 30 enterprises as representative sample of 66 enterprises. The study found result that 10 enterprises prepared income statement, 14 SME prepared cash flow statement and 6 small and medium enterprises prepared all statement. Under Appendix researcher displayed that as Appendix 3. 33.3 percent enterprises prepared income statement 46.7 percent prepared cash flow statement and 20 percent prepared all statement. At the time of data collection researcher did not have detail information about the statement.

Audited financial statement: Equipped audited financial statement was rare scenario in SMEs in Rangpur. In Rangpur only 6.7 percent enterprise provided audited financial statement to the partner, investor and the external parties while 93.3 percent did not prepared audited financial statement are shown in Appendix 4. To find out the result researcher used yes and no response. Twenty enterprise provided audited financial statements are Karuponno Company (A Kashim and Co) and Naoyar Hosto shilpo (Jamil Ahmed and Company). It is a fact or truth that helped a researcher to get clear understanding of accounting system in SMEs in Rangpur (Tables 1 and 2).

Quality information: Quality information of accounting is the most driver of the enterprise because quality of information represents accuracy, timeliness and consistency of the records and transaction. Data presented in the Table 3 showed that 12 SMEs used accuracy as quality of accounting information, 6 SMEs that the as quality of accounting information while 2 and 9 enterprises followed consistency and none of accounting information. Researcher used value $1,2,3,4$. $1=$ accuracy, $2=$ timeliness, $3=$ consistency and $4=$ none (didn't follow any quality of information). The result showed that 40 percent enterprises used accuracy as quality information while 20.7 percent and 6.9 percent timeliness and consistency respectively and 31 percent enterprises none of quality information of accounting shown in Appendix 5.

Accounting methods and basis used by SMEs in Rangpur: Accounting methods and basis followed are classified in two categories but after completed survey in 3 enterprises researcher had put another option that is unknown (method \& basis both) because most of the SMEs in Rangpur did not used any accounting methods and basis.

40 percent enterprises used double entry system of accounting methods and while 30 and 30 percent used single entry and unknown or no methods respectively in the SMEs. Most of the entrepreneur of the sole proprietorship business did not know about accounting methods, hence the researcher needed to assume it on the basis of their various papers.

43.33 percent used cash basis while 16.67 and 40.0 percent used accrual basis and unknown basis in the SMEs and their frequency level were 13, 5 and 12 respectively (Appendix 6).

Entrepreneurs have accounting knowledge: Entrepreneur and employer are the main character of the enterprises. The entrepreneur

\begin{tabular}{|c|c|c|c|c|}
\hline $\begin{array}{c}\text { Category of } \\
\text { Enterprises }\end{array}$ & $\begin{array}{c}\text { No accounting } \\
\text { skills }\end{array}$ & $\begin{array}{c}\text { Below } \\
\text { average }\end{array}$ & Average & High skills \\
\hline Sole proprietorship & 30 & 10 & 7 & 0 \\
\hline Partnership & 14 & 5 & 3 & 2 \\
\hline Private limited & 2 & 2 & 2 & 3 \\
\hline Percentage & $\mathbf{5 7 . 5 \%}$ & $\mathbf{2 1 . 3 \%}$ & $\mathbf{1 5 \%}$ & $\mathbf{6 . 2} \%$ \\
\hline
\end{tabular}

Source: primary data from survey

Table 1: Employees having accounting knowledge. 
and manager who have accounting knowledge they used it in their enterprises but still having accounting knowledge some entrepreneur did not follow or use it in the SMEs.

13 entrepreneurs have accounting knowledge and 17 entrepreneurs didn't have accounting knowledge and their percentages were 43.3 and 56.7 percent respectively Appendix 7. The entrepreneurs those have accounting knowledge majority are heard from other entrepreneur and did not know how to apply and some were still having knowledge ignore it.

Number of employees in SMEs: Number of employees worked in the SMEs is ranged from 1 to 250. On the basis of Appendix 8, the enterprises constituted 1 to 99 employees are called small enterprise and having 100 to 250 employees are called medium enterprises. SMEs small or medium is considered on the basis of two view, these are investment view and employee view. To the study researcher considered investment view to measured enterprise types. $1=$ represent 1 to 25 employees, $2=26$ to 50 employees, $3=51$ to 75 employees, $4=76$ to 100 employees, $5=101$ to 150 employees and $6=151$ to 250 employees of the enterprises in Rangpur. Based on the employee size the enterprises were classified into three categories as very small, small and medium enterprise.

Employees having accounting knowledge: For knowing the actual accounting phenomena in SMEs researcher classified enterprises in three categories such Sole proprietorship, Partnership and Private limited.

Considered $\mathrm{n}=80$ (30 entrepreneur and 50 employees of the selected enterprises). Table 1 showed that 57.5 percent entrepreneur and employees did not have accounting knowledge while 21.3 percent, 15 percent and 6.2 percent have below average, average and high skills of accounting system.

Accounting system and performance of SMEs: To measure impact of accounting system on performance of SMEs was a difficult work for the researcher. The researcher didn't have any yearly progress records and profit or loss percentage from the respondent enterprises (Table 2).

Furnished the overall result of SME performance. Though economic growth of SMEs in Rangpur is increasing in small enterprises but due to use accounting system medium enterprises are able to take better economic decision which help to earn high profit in medium enterprises. Impact of poor accounting system in SME entrepreneur did not know how to run the business and proper investment decision.

Needs of accounting system to increase enterprise performance: Accounting is called language of business. It records reliable information, prepare financial statement for measuring financial performance, maintain accuracy of the transaction, and provide financial statement to the investor and credit sector and other related function. $80 \%$ enterprise used accounting system indirectly that means most of the enterprises didn't properly used accounting system or they used accounting as per their need without follow any rules and principles. To the study researcher collected data from 30 enterprises and the findings showed that entrepreneur provided answer both yes, no and no need (Figure 2).
To describe the presented data on the graph researcher classified value in three categories. Here $1=y e s$ accounting increase firms performance, $2=$ no accounting didn't increase firms performance and $3=$ no need of accounting. Graph showed that 43.3 percent responded yes while 13.3 and 43.3 percent responded no and no need of accounting for increasing performance of SMEs respectively shown in Appendix 9 (Table 3).

On the above cross tabulation sheet result showed that among 13 enterprises those entrepreneur and employees have accounting knowledge 7 entrepreneurs answered yes 1 and 5 answered no and no need respectively. On the other hand among 17 enterprises entrepreneur 6 entrepreneurs answered yes while 3 and 8 answered no and no need respectively.

Accounting system and better decision: Though this is the era of modern accounting system all over the world small and medium enterprises those are situated in Rangpur still not properly followed accounting system.

60 percent enterprises didn't think accounting system helpful for taking better decision to their enterprises while 40 percent enterprises think it's helpful for taking better decision making shown in Appendix 10.

Accounting system and growth of SME in Rangpur: Though establishment of small enterprise in Rangpur is increasing day by day but without followed accounting system in these enterprises economic growth is lower than medium enterprise. Most of medium enterprises used accounting system and had control over all activities including purchasing raw materials to selling products to customers which helped to earn more profit. The growth of accounting system of SMEs in Rangpur is better than medium enterprise but growth of medium enterprise high while growth of small enterprises are medium, average and low not high. Illustrate Appendix 11.

\section{Increase SMEs Performance}

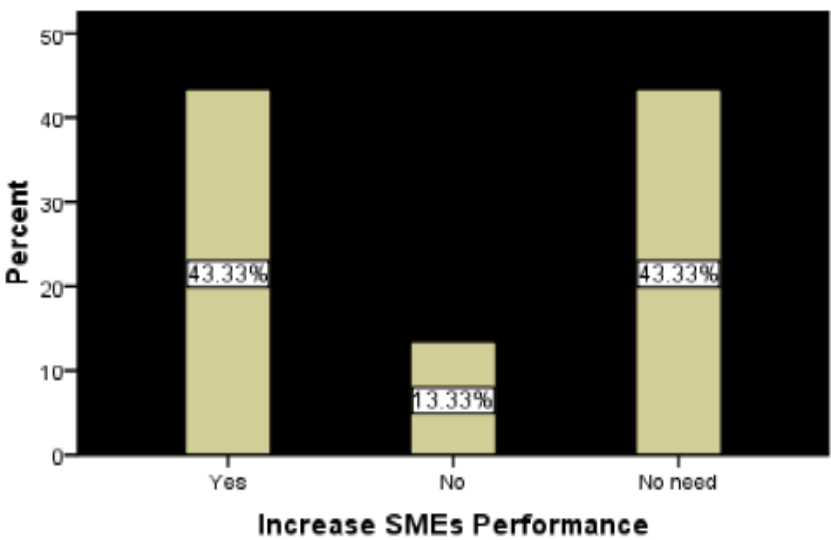

Figure 2: Accounting system to increase enterprise performance.

\begin{tabular}{|c|c|c|c|c|c|c|}
\hline SMEs & $\begin{array}{c}\text { Economic growth in } \\
\text { Rangpur }\end{array}$ & $\begin{array}{c}\text { Job creation for } \\
\text { employees }\end{array}$ & Profit Earning & Credit facilities & $\begin{array}{c}\text { Price of the product } \\
\text { Proper investment } \\
\text { decision }\end{array}$ & $\begin{array}{c}\text { Business run } \\
\text { Small }\end{array}$ \\
1.35 & Average & Low & NGO & Average & Low \\
\hline Medium & .67 & High & High & Bank & Above average & High \\
\hline
\end{tabular}

Source: Primary data

Table 2: Accounting system and performance of SMEs 
SME's Contribution in GDP: Bangladesh experienced a steady rise in GDP growth during last ten years (2003-2012) growing at an average annual rate of more than 6 percent compared with 5 percent over the previous five years. Higher growth, together with a fall in population growth to less than 1.5 percent in recent years, led to a rapid growth in per capita GDP.SME sector significantly contributes to GDP and its rate is increasing over time. In FY2010-11 SMEs contribution was $11.50 \%$ which increased to $19.1 \%$ in 9 years. It is also obvious that the major contribution comes from larger and medium scale industries contributing about $17.10 \%$ in fiscal year 2014-2015(P) were shown in Appendix 12.

The contribution of SMEs in GDP is increasing every year except 2013-14. The figure again reveals that except 2010-2011 contribution of small enterprises to GDP is higher than medium enterprises because in 2010-2011 contribution of medium enterprises to GDP was higher than small enterprises. The figure showed that in year 2014-15(P) contribution of small enterprise to GDP is higher than previous year. Bangladesh Bureau of Statistics express their opinion that establishment of small enterprise and initiative work by young generation for selfemployment increase the contribution of small enterprise to GDP.

SME's (Rangpur) contribution in GDP: After 2000 various types of SMEs had been grown in Rangpur. Common SMEs in Rangpur are papos, shotoronji, doormate, table mate, leather and leather product, agro product, plastic product, poltry firm, fishing, hachary, produce cotton and cotton product, parlour and wood furniture, backary and narchary etc. Contribution of Rangpur in GDP by SMEs is increasing day by day. Though contribution of Narayon gong SMEs in GDP compared to Rangpur is very high but it shows a positive figure day by day in GDP.

The contribution of SMEs in Rangpur in GDP is increasing day by day. Graph again revealed that though contribution of small enterprises is higher than medium enterprises the average contribution of SMEs to GDP is increased continuously. Yearly contribution of Rangpur in GDP by SMEs was shown in Appendix 13.

Price and quality of SME products: To investigate the price and quality of SME product researcher selected 18 customers randomly. All of them are like to purchase SME product and wants to improve domestic enterprise and tries to abdicate foreign product. Sample customers provided opinion that rest of some product price of the SME product is reasonable, medium and average.

Though most of the SMEs in Rangpur didn't followed accounting system directly but quality of the product was not low. The entrepreneurs and employees produce products with hard work and coordinal love. Hence they do not know any methods, formula but they solely prepare design, select ingredients and color that looks a product so beautiful. According to customers view point quality of SME product are classified in three categories these are high, medium and average. Here researcher was mentioned low scale but none of one customer put Tick $(\sqrt{ })$ Markon low quality of SME product. The graph showed that percentage of high quality is 10 percent while medium and average were 50 percent and 40 percent respectively shown in Appendix 14 .

\section{Hypothesis testing}

The Chi- Square Test: To the study researcher used Chi- square test. Because the Chi- Squaretest of hypothesis is a hypothesis for experiments with two categories. Chi-square distribution has only one parameter called the degree of freedom (Table 4).

The above test showed that calculated value chi-square $=10.008$ but the tabular value of chi-square for the $\mathrm{df}=1$ at the $99 \%$ confidence level is 7.879. So calculated value chi-square is greater than tabular value i.e., $10.008>7.879$. Hence this study suggests to reject the null hypothesis and to accept the alternative hypothesis.

Decision: Null hypothesis is rejected and alternative hypothesis is accepted. So the result showed that directly or indirectly SMEs of Rangpur follow accounting system.

Reason for using Chi- square test: To find the actual result of hypothesis researcher used chi-square test because if researcher used t-test then $\mathrm{df}=29$, critical value $=1.699$ and tabular value or computed value is 24.33 which gives inaccurate result.

\section{Limitations to implement accounting system in SME}

The research showed result that among 30 enterprises 13 enterprises entrepreneurs and employer has accounting knowledge but only 6 enterprises used accounting system properly. Those 6 enterprises used accounting system entrepreneurs of the enterprise still unable to used standard accounting system. The remaining 17 enterprises have a major setback of accounting knowledge. The entrepreneur and employer of the enterprises follow some functions of accounting system as per their need but they didn't know accounting system and entire criteria or methods of accounting system. The limitation of SMEs to implementing accounting system are describes under; Most of the entrepreneur and employee don't have adequate knowledge about accounting system, The entrepreneur thinks it is time consuming process, Lack of manpower, Lack of regulatory policies, It is expensive process, It requires more staff, It requires technical skills and knowledge, It is difficult to maintain the system, There is no need to keep accounting records, Thinks that without accounting system its run perfectly.

\begin{tabular}{|c|c|c|c|c|c|}
\hline \multicolumn{6}{|c|}{ Count } \\
\hline & & \multicolumn{3}{|c|}{ Increase SMEs Performance } & \multirow{2}{*}{ Total } \\
\hline & & Yes & No & No need & \\
\hline \multirow{2}{*}{$\begin{array}{c}\text { Have accounting } \\
\text { Knowledge }\end{array}$} & Only Entrepreneur & 7 & 1 & 5 & 13 \\
\hline & $\begin{array}{l}\text { Entrepreneur and } \\
\text { employee }\end{array}$ & 6 & 3 & 8 & 17 \\
\hline \multicolumn{2}{|r|}{ Total } & 13 & 4 & 13 & 30 \\
\hline
\end{tabular}

Table 3: Have accounting Knowledge - Increase SMEs Performance Cross tabulation.

\begin{tabular}{|c|c|c|}
\hline & & Follow Accounting System \\
\hline \multicolumn{2}{|c|}{ Chi-Square } & 10.8 \\
\hline \multicolumn{2}{|c|}{ df } & 1 \\
\hline \multicolumn{2}{|c|}{ Asymp. Sig. } & 0.001 \\
\hline \multicolumn{3}{|c|}{ Table 4: Test statistics. } \\
\hline Dependent variable & Independent variable & Computed value "r" \\
\hline \multirow{7}{*}{$\begin{array}{l}\text { SMEs followed } \\
\text { accounting system }\end{array}$} & Kept accounting records & $0.892^{* *}$ \\
\hline & Prepared financial statement & $0.892^{* *}$ \\
\hline & Method of accounting & $-0.408^{N S}$ \\
\hline & Basis of accounting & $0.479^{\star *}$ \\
\hline & Audited financial statement & $-0.501^{* *}$ \\
\hline & Quality Information & $0.496^{\mathrm{NS}}$ \\
\hline & Accounting knowledge & $0.328^{* *}$ \\
\hline
\end{tabular}

NSNot significant

*Significant at 0.05 level of probability

**Significant at 0.01 level of probability

Table 5: Multiple co-relation of coefficient showing relationship between selected independent variables with dependent variables. 


\section{Major findings of the study}

Findings showed that among 30 enterprises 24 enterprises used accounting system indirectly in Rangpur. Within selected 30 enterprises 80 percent used voucher as records of documents. Financial statements are income statement, cash flow statement, balance sheet, owner's equity statement and notes and disclosure. The researcher selected 30 enterprises as representative sample of 66 enterprises. The study found result that 10 enterprises prepared income statement, 14 SME prepared cash flow statement and 6 small and medium enterprises prepared all statement. Accounting methods are followed by SMEs with a mean of 1.90 and standard deviation of 0.845 . Based on respondent's enterprises researcher classified accounting method into three categories as double entry, single entry and unknown. Accounting Basis indicated that 43.3 percent of the enterprises had followed cash basis accounting, 16.7 percent enterprises had followed accrual basis of accounting and 40.00 percent had not followed any basis of accounting with a mean of 1.97 and standard deviation 0.928. Prepared audited financial statement was a rare scenario in SMEs in Rangpur. Among 30 SMEs as sample among these only 2 enterprises prepared audited financial statement with a mean 1.93 and standard deviation 0.254 . In Rangpur only 6.7 percent prepared audited financial statement and 93.3 percent did not prepared audited financial statement. Again the study reveals that growth of small enterprises is higher than medium enterprise but its scale were medium, average and low while the growth of medium enterprise was high. To get clear understanding about SMEs researcher investigate the price of the product. The study showed that price of the SME's product is medium and reasonable and quality of the product is high and medium (Table 5).

\section{Conclusion and Recommendation}

This study is empirical in nature that evaluates accounting system in small and medium enterprise and explores the relationship of the selected function or methods of accounting on small and medium enterprises of Rangpur. Most of the enterprises follow single entry accounting system. The study reveals that lack of accounting knowledge of the majority of SMEs in considering with practicing the operation. To accomplish this task questionnaires comprising various aspect of accounting system of SMEs were administered in the course of data collection, hypothesis was formulated and tested where the alternative hypothesis was selected. Findings show that an effective accounting system in small and medium scale enterprises has profound impact on their corporate performances. Thus accounting systems show the books, records, voucher, and files and related supporting data resulting from the application of the accounting process of the studied enterprises. So, this study examines the profiles of accounting information usage in SMEs in north districts of Bangladesh. From the results, researcher has found that there are several notable observations regarding the use of accounting system. This study found that the level of awareness on the importance of financial management is still to apply accounting system very low in small and medium firms. Most of the managers do not aware the importance of keeping a good accounting records. This record must be in an orderly manner and complete with all the important data regarding their business transactions. The enterprises are in constant development, a major characteristic of Small and medium enterprises are growth rate was significantly higher than large enterprises. Their markets reach, customer characteristics, mode of operation and other aspects of change is much more frequently than large companies, the business processes of stability is much smaller. Therefore, small and medium business accounting process reengineering cannot be a onetime success. For keeping constant development stable entrepreneur needed to follow accounting in enterprise. SMEs are asked to express their opinion of what could be done to improve the accounting practices of SMEs. A list of some suggestions presented to respondents. These are presented below and it is observed that the respondents agree that "educating managers and owners on the need to keep accounting records" is the best solution. This is in agreement with the fact that most of the respondent who does not keep the records believes that it is not useful to keep accounting records, Organize training for managers and owners, Hire consultants for SMEs for financial statement analysis, Make the use of accounting records mandatory, Offer free accountancy services. Motivate managers/owners to adopt accounting records, Strengthen monitoring and supervision, Edify managers/owners on the need to keep accounting records., Provide more potential training center and courses for SMEs.

\section{References}

1. Maseko N, Manyani O (2011) Accounting practices of SMEs in Zimbabwe: An investigative study of record keeping for performance measurement (A case study of Bindura). Journal of Accounting and Taxation 3: 171-181.

2. Amako GK (2013) Accounting practices of SMEs: A case study of Kumasi metropolis in Ghana. International Journal of Business and Management 8: 73-83.

3. Ismail NA, King M (2007) Factor influencing the alignment of accounting information systems in small and medium sized Malaysian manufacturing firms. Journal of Information Systems and Small Business 1: 1-20.

4. Zhou $L$ (2010) The Research on issue and countermeasures of accounting information of SMEs. International Journal of Business and Management 5 : 223-225

5. Okoli BE (2011) Evaluation of accounting systems used by small scale enterprises in Nigeria: The case of Enugu- South East Nigeria. Asian Journal of Business and Management 3: 235-240.

6. Fatoki O (2012) An Investigation into the financial management practices of new Micro-Enterprises in South Africa. Journal of Social Science 33: 179-188.

7. AL Smirat BY (2013) The use of accounting information by small and medium enterprises in south District of Jordan, (An empirical study). Research Journal of Finance and Accounting 4: 169-175.

8. Olatunji TE (2013) The Impact of Accounting System on The Performance of Small and Medium Scale Enterprises in Nigeria-A Survey of SME's in Oyo State-Nigeria. International Journal of Business and Management Invention 2: 13-17.

9. Velankar N, Gupta RC, Garud U (2013) E-accounting practices among SMEs: A study of M.P. REGION. Journal of Management Value and Ethics 3: 94-106.

10. Ntim AL, Evans O, Anthony F (2014) Accounting Practices and Control Systems of Small and Medium Size Entities: A case Study of Techiman Municipality. Journal of Finance and Accounting 2: 30-40. 